\title{
Identifying and Ranking the Obstacles of Internal Controls Evaluation in the External Audit Process
}

\author{
Javad Ardi \\ Department of Accounting, Hamedan Branch, Islamic Azad University, Hamedan, Iran.
}

\section{Mohammad Nazaripour}

Department of Accounting, University of Kurdistan, Sanandaj, Iran Corresponding Author. E-mail: mnazaripour@yahoo.com

Doi:10.5901/mjss.2015.v6n6s2p613

\begin{abstract}
Internal control evaluation is a risk-assessment process utilized by both a firm and its auditor to assess various aspects of the firm's accounting information system. Accounting internal control systems which are affected by an entity's board of directors, management, and other personnel are designed to provide reasonable assurance regarding the effectiveness and efficiency of operations, the reliability of financial reporting, and compliance of the organization with laws and regulations. The purpose of this study is to identify the most important obstacles of internal control evaluation in the external audit process from the viewpoint of companies' managers and external auditors in Iran. The research period was fall 2014 and the research data was gathered through a questionnaire. In order to test validity and reliability of questionnaire, factor analysis and cronbach's alpha were used respectively. Kolmogorov-Smirnov test, T-test and Chi-square test were used to test hypotheses. Friedman test was used to rank the identified obstacles. According to the research findings, from the managers' viewpoint issues such as lack of higher education, being traditional accounting systems and lack of proper auditing guidelines were the most important obstacles. From the external auditors' viewpoint, issues such as lack of affordable of internal control evaluation, lower audit fees and lack of professional training were the most important obstacles.
\end{abstract}

Keywords: External Audit, Internal Controls Evaluation, Auditors, Managers, Iran

\section{Introduction}

Daily improvement and complexity of economical units, continuous technological progress, increased turnover, lack of resources, increased competition, variety of dangers treating the goals and policies of organizations were the cause to capture the mind of management in to the many problems.so direct and individual control of these units became impossible. For this reason, need to establish effective internal control systems have been considered as an integral component of an efficient management system. Internal control system is a dynamic system which covers variety of risks, deviations from policies and procedures. Evaluation and design of internal control system is of vital importance for the management. Since management is responsible for the financial statements and internal control system, implementation of internal audit to assess the performance of the internal control system, has grown increasingly. Independent auditors to identify and evaluate the risk of material misstatement due to fraud or error in the financial statements and design and implementation of the necessary audit procedures should get enough knowledge about verifying unit and its area including internal controls. In fact, system of internal control is evaluated from inside and outside of the organization (Malekian, Tavakolnia, \& Pakdelan, 2014). Evaluation of internal controls in independent audit can be programmed based on goals such as identifying financial statements audit purposes, developing the overall audit plan, the initial estimate of risk control and risk detection. Recognition of internal controls in independent audit is necessary and inevitable. This recognize is used to identify types of distortions, verifying potential factors affecting the risk of important distortions and designing the content test (preparation committee for standard accounting, 2010).

The ultimate goal of the audited financial statements is to reduce the audit risk to an acceptable low level for commenting on the financial statements. Because of the interrelationship between the components of audit risk (the risk control is one of the main components), evaluation of internal control is essential. If there are no effective internal controls, or do not act effectively, performing independent accounting will be more expensive and difficult and will follow consequences for independent audit report (Maham, 2002). Preparation of reliable financial information from the audited 
financial statement, will follow assurance about the information presented in the financial statements, but in the auditing financial statements, assessing the effectiveness of internal controls are considered as fundamental steps (Vadiee \& Kouchaki, 2008). The evaluation of auditors from internal controls on business units will have effect on audit planning management. In today's world, generally increasing the quantity and quality of independent auditing is possible and feasible through greater reliance on internal controls (Maham, 2002) It is interesting that the securities and exchange organization recently approved and promulgated the procedures of internal controls. And in the near future, submitting the report of the management report about internal control and report of the independent auditor related to that will be necessary (Tehran Stock Exchange Organization, 2012). However, in general, accounting systems and internal control are not going to be recognized, registered and evaluated well by the audit farms. In other words, available evidence indicates that auditors are not showing sufficient efforts to meet the goals of the standards and requirements (preparation committee for standard accounting, 2010).

Lack of effective and efficient internal controls, have been overshadowed many of our country s business units. Those companies that their internal controls are well designed, can prevent the problems that will be created in the absence of controls. Lack of effective internal controls, not only on operation of business units but will have negative impact on quality of the independent audit process (Maham \& Pooryanasab, 2004). In auditing standard 315, as understanding the entity unit, and its area and estimation of errors of important misstatement is insisted and auditor should recognize the internal controls associated with financial statements auditing. Auditor's understanding of internal controls, to identify the types of potential distortions, uses assessing affecting factors on risks of important misstatements, nature design, timing and audit procedures measurement (preparation committee for standard accounting, 2010). In auditing standard 330, as audit procedures to address the estimated risks is stated that in cases where the risk of important misstatement at the assertion level by the auditor is a function of internal control, auditor must act the controls test to get enough and suitable accounting proofs about control execute effectiveness at different times during control. (preparation committee for standard accounting, 2010). Despite the emphasis of auditing standards 315 and 330, on evaluating the internal controls as one of the essential steps in accounting, available data indicates that auditors do not have sufficient efforts to meet the goals of the standards and their requirements. This will bring the auditing quality of financial statements under question. The main question that arises here, is that, what are the main obstacles of internal control evaluation in auditing process?

With regard to the evaluation sensitivity of internal controls in effectiveness of independent auditing process, in this research, it has been tried to determine the main barriers of evaluation and the reasons in internal controls of independent auditing process. In this research, with using the viewpoints of manufacturing companies and partners of auditing companies as well as the viewpoints of experts and professors in the field of audit, will investigate the barriers of internal controls evaluation in the audit process.

\subsection{Importance of Subject}

As mentioned, internal controls evaluation in independent auditing will be done according to goals like identifying the financial statements of auditing, overall audit plan initial estimation of risk control and risk detection of losing plan. Recognition of internal controls in independent auditing is necessary and inevitable. This knowledge is used to identify the types of potential distortions, verifying affecting factors on risk of important distortions and designing substantive tests. Today, with the creation of computerized accounting system, there is a great change in the establishment of appropriate internal controls and inside financial unit relation with other units within the organization.

In our country, for many years, governmental units, had financial computer systems such as payroll system, property system, Transportation, uniform system of products, contractors system and budget. Despite the strong power of computer in processing correct and accurate information, there is possibility of misuse and abuse also. Since using the computer, too much information is processed, effect rate of mistakes and probable misuses will be increased. Therefore, study, evaluation and proper auditing of such systems are very important. The purpose of this study is to investigate strength and weakness points in using new information technology on different areas of the company's audit. The researcher hopes with doing this research will have an effective step in the identification and evaluation of the strength and weakness points of internal control system.

\subsection{Objective}

The study has the following objectives in mind:

1) Counting the barriers to evaluate internal controls in independent auditing. 
2) Identifying the underlying causes of barriers to evaluate internal controls in independent auditing.

\section{Literature Review}

In their research, Bani Mahd (2012) studied the effective factors on auditor's unqualified opinion. In their study, they reviewed the effect of factors such as management performance, change of ownership, privacy, size of company, auditing, selection of auditor and ..... on unqualified opinion, and found out that all variables of the study except for company size, has direct relationship with possibility of issuing unqualified audit report. Ebrahimi Kordlar et al (2008) in their research demonstrated, there is a direct association between independent auditor and earnings management relation. In this investigation, they divided the type of auditor in to auditing organization and private sector audit institutions. The result of their study represented that in total the companies that get audited by audit organization, have less profit management. Rajabi et al (2008) in reviewing the agency costs and pricing of accounting services within a period of one year, i.e. 1384, using correlation study found that there is a significant relationship between the index of agency costs and remuneration of audit services. Sajjadi et al (2005) studied the increasing factors of independence of independent auditor from the perspective of Iran accountants' society of registered auditors. Using questionnaire, they showed that from independent auditor's point of view, the employer audit committee, size and experience of audit firms, the size of employer firm are accounted as multiplicative factor of independence and competition in accounting profession is as reducing factor of auditor's independence. Sajjadi et al (2003) in reviewing the usefulness of independent auditing of financial statements from perspective of financial managers of Tehran stock exchange's listed companies, in a survey study, using questionnaire found that, in terms of financial managers of mentioned companies, the independent accounting is helpful for discovery and reducing the possibility of fraud, illegal acts and exact evaluation of essential principals for accounting estimates.

Jameei et al (2012) in their research reviewed the effect of managers' performance on independent auditor's opinion in listed companies of Tehran Stock Exchange. The results of hypothesis tests indicates the effect of EPS measure (earnings per share) on the report of independent auditor, the measure of profitability per share, ROA rate and return on equity, all influences the clause of obtaining the approval of conditional report of the independent auditor. Considering the findings of the research can express that improving the management performance reduces the issuance of the conditional report (qualified report), as the result, the accounting standards of management performance influences the independent auditor's opinion. The results of their research is representative that the stability of management in high level of quality and profitability that belongs to shareholders, increases the probability of receiving unqualified report. It should be noted that earning per share has very little impact on representing unqualified audit report. Meanwhile increase in level of conservatism applied by management, rises the probability of receiving unqualified report by auditor. Maham et al (2012) in their investigation examined the barriers to internal control evaluation in auditing. The statistical population of this research was composed of audit firm's partners of Iranian Association of Certified Accountants. In order to obtain viewpoints of population members, a questionnaire composed of 6 hypothesis and 27 questions was designed, and was distributed among 100 members of the population who were selected randomly. Finally, 80 questionnaires were filled out by members of the selected sample. After collecting opinions (viewpoints), statistical tests were conducted. The results of the research showed that low fees of audit contracts, poor academic training, suitable audit instructions, traditional system of commercial units, not being cost effective the internal control evaluation and poor professional training are respectively of the most important barriers of internal control evaluation in Iran independent audit.

Rezaei et al (1996) reviewing the evaluation of the amount of independent auditors reliance on addressed companies internal control concluded that system-based audit approach isn't fully implemented. He identified the following problems in this regard: inadequate training of auditors in college, widespread confusion about identification and evaluation of internal controls, lack of profound attitude and lack of proper professional standards, high probability of violating internal controls in behalf of the management, inadequate internal controls' procedures for the purpose of controlling, being time-consuming of control tests compared with positive tests and finally lack of an integrated and desired system of internal control in most companies. Ghadimi (2004) studied the auditing standards developed by professional credible foreign countries; professional credited foreign countries and internal publications in regard of the evaluation of internal controls, and came to this conclusion that Iran does not have sufficient audit standards in order to assess the effectiveness of governmental companies' internal control. Vadiee and Kouchaki (2008) through reviewing the effectiveness of internal controls of companies resulted that the companies ' internal controlling system in order to achieve economic goals is inefficacious and the independent auditors' assessment of these controls for performing audit procedures is not effective.

Abdul nasser et al. (2006) In a study of 297 companies in a period of 11 years in Malaysia found that in order to 
receive a more favorable audit report in companies, possibility of changing an auditor with insufficient profitability and poor performance is higher in compared with the year before. Geiger et al (2005) showed, issuing unqualified audit report about continuity of activities is under the influence of factors such as company size, profitability, auditing time, type of industry, diversity of auditor and type of audit report in the year before. Hudaib (2005), in reviewing the effect of change management on type of audit opinion and change of auditor in England found that the companies which had poor performance and management change, have received more audit report than other companies, and this subject causes change in companies' auditor. Bell and Tabor (1991) in their investigation concluded that rate of return on equity, inventory turnover ratio, accounts receivable turnover ratio, current ratio and financial gearing, have the ability to predict the qualified audit report. In a study in Malaysia, Gul (1989) examined the impacts of several factors such as competition, the employer credit committee and the size of audit firm on independence of auditor, and resulted that competition among audit firms has positive effect on independence of auditor, but size of audit firm effects negatively and also the auditing committee didn't matter from the views of subjects. Agaser and Doupnik (1991) reviewed the effect of non-audit services, deferred (arreared) fees, size of the company surveyed and a working spouse of auditor in the audit firm on independence of auditor in three countries of America, Germany and Philippines, and got to the result that except for deferred fee, other factors don't have decisive impact on the independence of the auditor. Lindsay (1990), in a study which was done in Canada concluded that from the perspective of managers of credit institutions and banks, competition in auditing profession and size of audit firm have positive effect on independence of auditor.

In a research that was conducted in U.S.A, Bartlett (1993) concluded that from perspective of independent auditors and managers of credit institutions and banks, the size of employer company has decreasing effect on auditor's independence. With the exception that in compare with managers of banks and credit institutions, independent auditors have less concerns. Thoh and Lim (1994) in a research in Malaysia reviewed the effect of several factors such as the employer audit committee's effect on independence of auditor. The results of research revealed that of independent audits and working accountants' point of view in Production Companies, existence of employer audit committee has positive effect on auditor independence. Beattie et al (1999) in a study in England examined 25 multiplicative factors of auditor independence including competition in audit profession, the size of employer company and employer audit committee. The results of the research showed that from perspective of financial managers of companies, audit committee and financial analysts' of mentioned 25 factors, competition, size of employer company and audit committee are the most important multiplier factors of independence among these 25 factors. Park (1990) reviewed the effect of competition on independence and quality of audit work in South Korea, and came to conclusion that the managers who had received conditional reports have changed their auditors more than managers who had received unqualified reports. Moreover, the managers were more likely to receive more unqualified reports in subsequent audits. Park concludes that competition provides a new opportunity to employer managers to choose their favorite auditors. He goes on to say: for governments and professional associations, the main objective of competition is to enhance the audit quality. But this aim is achieved once the employer managers have sufficient reputation and choose competent and professional auditors. It seems like two factors of audit firm's structure (the application of quality control) and employer management (choosing an auditor with top independence and quality) can benefit from competition to enhance auditor independence. On the contrary, these two factors can misuse the competition and fade the independence.

International Federation of Accountants (2001) in Code of Professional Conduct stats: if audit committee is independent of management and can convince the management in relation to independence, can have an important supervisory role. Independence Standards Board (ISB) (1999) asks each accountant to report all of relationships among auditor and Employer Company which effects the auditor independence and judgment to Employer Audit Committee. Institute of Management Accountants, UK (2001) believes that the role of employer audit committee is much more than being interface between the company and the auditor. And emphasizes that the employer audit committee should have a key role in the selection of independent auditor. Large companies often have stronger internal control mechanisms and try to choose auditors with higher quality. Irene Sklyf Research Institute (2000) in a report that submitted to Independence Standard Committee, about relationship between size of Employer Company and auditor independence says: for subjects, the size of a sword is double and most of subjects believed equal opportunity of misuse both for large and small companies. Large companies have stronger internal control and higher reporting quality. On the other hand, because of more audit fee (audit remuneration), auditors try to obtain auditing of these companies at any price. Although smaller companies have lower remuneration, they may have simpler audit. Auditors of these companies try to have friendly relations with employer; so the size (large or small) of company can leads to both increase (independence) and decrease in auditor's independence.

Large audit institutions have more reputation, and often cost more for training their auditors. And have stronger quality control. Dopuch and Simunic (1980) believe large audit firms invest greatly to increase their audit quality. For this 
reason, the Independence Standards Board (ISB) (1999) considers the credit and reputation of the company, the most important factor in protecting the independence. Park says larger audit should be able to be more resistant against employers' management; since either the pressure of employer is not high in these institutions or reputation and credit of the audit institution destroys the effect of this pressure. Crasewell et al (1995) in a research concluded that famous audit firms have higher prices and support their validity and fame furthur. Titman and Truemanm (1986) and Datar et al (1991) represented a model that demonstrates the positive relationship between audit firm's credit and its audit quality. Shockley \& Shceifler (1984) in a research he conducted concluded that from point of view of independent auditors and financial statements' users, the risk of losing independence in small audit firms is more. Beattie et al (1999) in their research showed that auditing a company by one of six large companies of the world, from company managers, the audit firm partners and financial analysts' perspective are respectively the second, second and nineteenth multiplier factor of auditor's independence among 25 multiplier factors of independence. On the other hand, from mentioned group's point of view, among 24 threatening factors of independence, auditing of a firm by a local audit firm is respectively fifth, third and sixteenth threatening factor of auditor's independence.

\section{Research Hypotheses}

1) Weakness of professional training prevented the assessment of internal controls in independent auditing.

2) Weakness of academic training prevented the assessment of internal controls in independent auditing.

3) Unaffordable of assessment of internal controls, prevented the assessment of internal controls in independent auditing.

4) Lack of appropriate auditing procedures, prevented the assessment of internal controls in independent auditing.

5) Low fee of auditing contracts in Iran prevented the assessment of internal controls in independent auditing.

6) Traditional system of business units prevented the assessment of internal controls in independent auditing.

\section{Methods}

Because this research, is to describe and study what was done, therefore this research from the view of conduct, is of descriptive researches.

Since in descriptive researches, we can assess the characteristics of under study society through surveys, this research is a descriptive study of survey kind. On the other hand, because of the presence of the researcher I real life of an organization, this research belongs to field study section.

In this research, researcher goes to auditing institutes, gets information from the auditing institutions, then distributes the questionnaire papers among them, finally obtain their suggestions about barriers in internal control assessment through information extracting from distributed questionnaires. And also after verifying the explanations by accounting experts, goes to some managers of manufacturing companies, distributes the questionnaires related to manager views about barriers of internal control assessment in independent auditing, then finally deals with evaluation of manager view of manufacturing companies.

\subsection{Statistical Community}

This research is included the partners of auditing institutions who are members of certified public accountants and society limited to partners of auditing institutions who are members of auditing society in Tehran city. Their members are about 700 .

\subsubsection{Statistical Sample}

The sample of this research was calculated by using the COCHRAN sampling formula:

With attention to the number of samples, the predicted probability of a number of questionnaires uncompleted or undelivered by staff, a total of 150 questionnaires were distributed among the partners of audit farms and their responses were received. And also 150 questionnaires were distributed among managers and financial experts of manufacturing companies. 


\subsection{Instrument}

In this research, data gathering tool is the questionnaire made by researcher. Indicators and components of the questionnaire is shown in Table 1 Method of scoring in the questionnaire, is the 5 points LIKERT scale method. Completely agree score is option 4 and completely disagree score is zero.

Table 1: Method of scoring in the questionnaire

\begin{tabular}{|c|c|c|}
\hline $\begin{array}{l}\text { Lack of Professional } \\
\text { Training }\end{array}$ & 1) & $\begin{array}{l}\text { Shortage of masters in professional education of audit issues } \\
\text { Inappropriate programs of continuous professional training and also they are up to date also. } \\
\text { Lack of education programs preparation by auditing farms about professional issues. } \\
\text { Insufficient seriousness of Iranian certified public accounts association in regard to continuous } \\
\text { professional education }\end{array}$ \\
\hline Lack of Academic Training & 5) & $\begin{array}{l}\text { Lack of coordination between university teachings with the needs of audit profession } \\
\text { Inadequate mastery of university professors in professional accounting issues } \\
\text { Lack of appropriate educational resources for professional audit issues. } \\
\text { University training system is traditional or it is not up to date. }\end{array}$ \\
\hline $\begin{array}{l}\text { Not affordable Cost for } \\
\text { Internal Control Assessment }\end{array}$ & $\begin{array}{l}\text { 9) } \\
\text { 10) } \\
\text { 11) }\end{array}$ & $\begin{array}{l}\text { The small size of most business units reviewed by the audit firm } \\
\text { Using non-qualified personnel and students at institutions of audit and non-audit its domination to } \\
\text { new issues } \\
\text { Seasonality of time pressure to complete the audit and audit procedures specified period of time }\end{array}$ \\
\hline $\begin{array}{l}\text { Lack of Appropriate Audit } \\
\text { Guidelines }\end{array}$ & $\begin{array}{l}\text { 12) } \\
13) \\
14)\end{array}$ & $\begin{array}{l}\text { Lack of proper interaction between auditors and audit firms to develop guidelines. } \\
\text { Research is expensive to develop audit guidelines to suit a variety of business unit activities. } \\
\text { Absence of large audit firms like auditing organization I Iran, so there is no competition between } \\
\text { audit firms and auditing organization in developing appropriate audit guidelines. }\end{array}$ \\
\hline Low Fees in Audit Contracts & $\begin{array}{l}\text { 15) } \\
16) \\
17)\end{array}$ & $\begin{array}{l}\text { Fast without procedure growth of auditing firms } \\
\text { Audit fee set by tender } \\
\text { General assembly`s mandate to the directors to determine the remuneration of corporate auditors }\end{array}$ \\
\hline $\begin{array}{l}\text { Traditional Systems of } \\
\text { Business Units }\end{array}$ & $\begin{array}{l}\text { 18) } \\
\text { 19) } \\
\text { 20) } \\
\text { 21) }\end{array}$ & $\begin{array}{l}\text { The lack of effective internal audit in a large company or not using them effectively } \\
\text { No competition among managers and their reliance on non-economic relations } \\
\text { Business unit managers do not believe in the necessity and effectiveness of internal control } \\
\text { Successive changes in managers of business units or lack of stability management. }\end{array}$ \\
\hline
\end{tabular}

\section{Results}

\subsection{Descriptive Statistics}

\subsubsection{Demographic Data of Respondents}

The general profile of respondents to the questionnaire are summarized in Table 2 to Table 4. As can be seen, most of the respondents to the questionnaire from the view of education are university graduates, and in terms of work experience are more than 20 years. 75 respondents were unit production managers and other 75 were partners of audit farms.

Table 2: Distribution of Educational Level of Respondents

\begin{tabular}{|c|c|c|}
\hline SUBJECTS & FREQUENCY & PERCENT \\
\hline EXPERT & 85 & 56 \\
\hline MA & 53 & 35 \\
\hline PhD & 12 & 8 \\
\hline SUM & 150 & 100 \\
\hline
\end{tabular}


Table 3: Working Experiences Status of Respondents

\begin{tabular}{|c|c|c|}
\hline SUBJECTS & FREQUENCY & PERCENT \\
\hline Less than 10 years & 40 & 26 \\
\hline 10 to 20 years & 32 & 21 \\
\hline More than 20 years & 78 & 52 \\
\hline Sum & 150 & 100 \\
\hline
\end{tabular}

Table 4: Working Position of the Respondents

\begin{tabular}{|c|c|c|}
\hline SUBJECTS & FREQUENCY & PERCENT \\
\hline Director & 75 & 50 \\
\hline Auditor & 75 & 50 \\
\hline Sum & 150 & 100 \\
\hline
\end{tabular}

\subsubsection{Statistical Parameters Describing the Components of the Research:}

To study the barriers of internal control evaluation in independent auditing, we used a questionnaire made by a researcher. In continue, we will deal with examining the descriptive statistics related to each of the components of the questionnaire.

Table 5: Mean score barriers components of internal control evaluation in terms of the independent auditing by managers and auditors

\begin{tabular}{|l|l|c|}
\hline Organizational post & Component & Mean score \\
\hline Managers & Lack of professional trainings & 3.14 \\
\cline { 2 - 3 } & Lack of academic trainings & 4.10 \\
\cline { 2 - 3 } & Not affordable cost of assessment of internal controls & 2.13 \\
\cline { 2 - 3 } & Lack of appropriate auditing procedures & 3.28 \\
\cline { 2 - 3 } & Low fee of audit contracts & 2.45 \\
\cline { 2 - 3 } & Traditional systems of business units & 3.55 \\
\hline Auditors & Lack of professional trainings & 3.61 \\
\cline { 2 - 3 } & Lack of academic trainings & 2.72 \\
\cline { 2 - 3 } & Not affordable cost of assessment of internal controls & 4.18 \\
\cline { 2 - 3 } & Lack of appropriate auditing procedures & 3.25 \\
\cline { 2 - 3 } & Low fee of audit contracts & 3.76 \\
\cline { 2 - 3 } & Traditional systems of commercial units & 3.10 \\
\hline
\end{tabular}

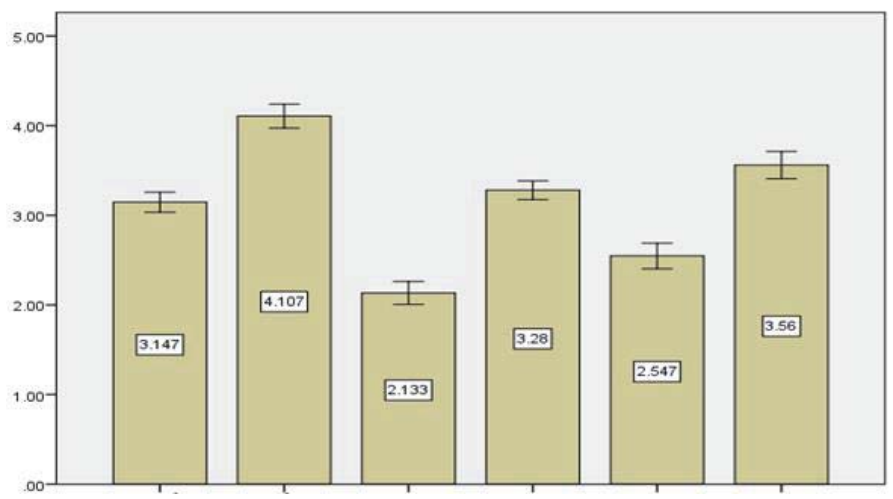

Figure 1: Score Average to Components of the Questionnaire from the Perspective of Managers 
As you can see in the above chart, barriers ranking of internal control evaluation in independent auditing from the perspective of managers in this case is:

1) Lack of academic training with a mean score of 4.10

2) Traditional system of business units with an average score of 3.56

3) Lack of appropriate audit procedures with an average score of 3.28

4) Lack of professional training with an average score of 3.14

5) Low fee of audit contracts with an average score of 2.54

6) Not affordable cost of internal control evaluation with an average score of 2.13

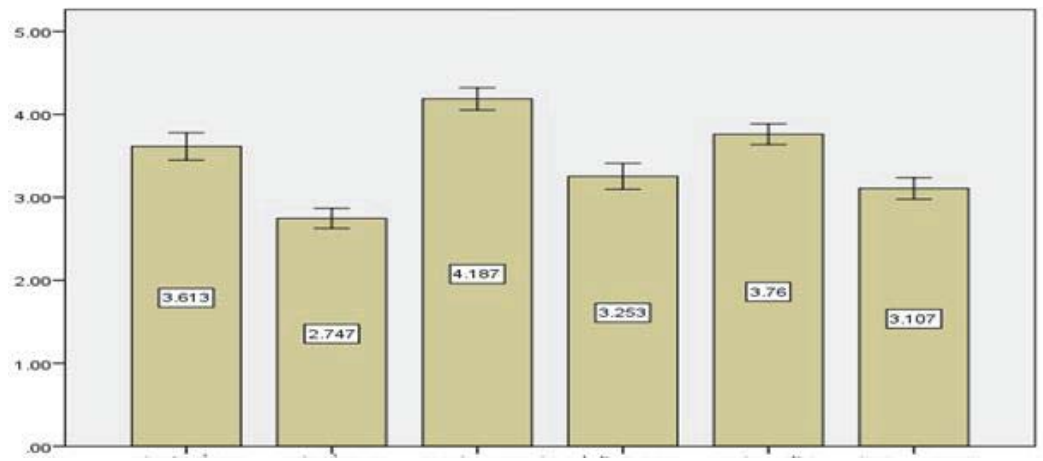

Figure 2: Score Average to Components of the Questionnaire from the Perspective of Auditors

As you can see in the above chart, barriers ranking of internal control evaluation in independent auditing from the perspective of managers in this case is:

1) Not affordable cost of internal control evaluation with an average score of 4.18

2) Low fee of audit contracts with average score of 3.76

3) Lack of professional trainings with an average score of 3.61

4) Lack of appropriate audit procedures with an average score of 3.25

5) Traditional system of business units with an average score of 3.10

6) Lack of academic training with mean score of 2.74

\subsection{Inferential Statistics}

\subsubsection{Exploratory Factor Analysis}

To identify the latent variables and confirm the validity of the measurement model analysis factor, we use the SPSS software and CRONBACH's alpha coefficient calculation. To do factor analysis, we must be sure that we can use the given data. By using CRONBACH's alpha coefficient calculation, we can be sure of sampling adequacy. This index is in the range of zero to one. If index is close to one, the given data is suitable for the factor analysis. Otherwise, result of factor analysis for given data is not suitable. In case, the amount of CRONBACH alpha is less than 0.50 , given data is not suitable for factor analysis. And if its amount is between 0.50 to 0.69 , then we can do the factor analysis with more care. If its amount is bigger than 0.70 , then the existing correlation between the data will be suitable for factor analysis. The result of exploratory factor analysis by SPSS software, with the advent of CRONBACH alpha of 0.83 , for the questionnaire used in this research, will be accepted basically.

\subsubsection{Evaluating the Research of Hypothesis:}

First Hypothesis: To determine whether the lack of professional training, precluding the evaluation of the internal control in independent auditing or not? The KHIDO test was carried out on the basis of responses received from the directors and partners of the audit firms. 
Table 6: Descriptive Information about the First Hypothesis by Administers

\begin{tabular}{|l|c|c|c|c|}
\hline & Observed amount & Expected amount & KHIDO value & Significant- level \\
\hline Very low & 0 & 15 & & \\
\cline { 1 - 3 } Low & 4 & 15 & \multirow{3}{*}{60.08} & \multirow{2}{*}{0.000} \\
\cline { 1 - 3 } Average & 56 & 15 & & \\
\cline { 1 - 3 } High & 15 & 15 & & \\
\cline { 1 - 3 } Very high & 0 & 15 & & \\
\cline { 1 - 3 } Sum & 75 & 75 & & \\
\hline
\end{tabular}

For managers, lack of professional training, with an average score of 3.14, prevents the evaluation of internal control in independent system. Since the response mode is average option, and according to KHIDO amount (60.08) and its significant level $(0.000)$ which is less than (0.01), about 99 percent we can say, lack of professional training prevents the evaluation of internal control in independent auditing.

Table 7: Descriptive Information about the First Hypothesis from Auditor's Perspective

\begin{tabular}{|c|c|c|c|c|}
\hline & The observed value & The expected value & KHIDI value & Significant level \\
\hline Very low & 0 & 15 & \multirow{6}{*}{41.32} & \multirow{6}{*}{0.000} \\
\hline Low & 2 & 15 & & \\
\hline Average & 33 & 15 & & \\
\hline High & 32 & 15 & & \\
\hline Very high & 8 & 15 & & \\
\hline Sum & 75 & 75 & & \\
\hline
\end{tabular}

For auditors, weakness of professional education, with an average of 3.61 prevents the evaluation of internal control in independent auditing. Since the response mode is average option, and according to KHIDO amount (41.32) and its significant level $(0.000)$ which is less than (0.01), about 99 percent we can say, lack of professional training prevents the evaluation of internal control in independent auditing.

Second Hypothesis: To determine whether the lack of professional training, precluding the evaluation of the internal control in independent auditing or not? The KHIDO test was carried out on the basis of responses received from the directors and partners of the audit firms

Table 8: Descriptive Information about the Second Hypothesis by Administers

\begin{tabular}{|c|c|c|c|c|}
\hline & Observed amount & Expected amount & KHIDO value & Significant- level \\
\hline Very low & 0 & 15 & \multirow{6}{*}{35.84} & \multirow{6}{*}{0.000} \\
\hline Low & 0 & 15 & & \\
\hline Average & 9 & 15 & & \\
\hline High & 49 & 15 & & \\
\hline Very high & 17 & 15 & & \\
\hline Sum & 75 & 75 & & \\
\hline
\end{tabular}

For managers, lack of academic training, with an average score of 4.10, prevents the evaluation of internal control in independent auditing. Since the response mode is high option, and according to KHIDO amount (35.84) and its significant level (0.000) which is less than (0.01), about 99 percent we can say, lack of academic training prevents the evaluation of internal control in independent auditing.

Table 9: Descriptive Information about the First Hypothesis from Auditor's Perspective

\begin{tabular}{|l|c|c|c|c|}
\hline & The observed value & The expected value & KHIDI VALUE & Significant level \\
\hline Very low & 7 & 15 & \multirow{4}{*}{$*$} & \multirow{2}{*}{0.000} \\
\cline { 1 - 3 } Low & 51 & 15 & & \\
\hline Average & 17 & 15 & & \\
\cline { 1 - 3 } High & 0 & 15 & & \\
\hline Very high & 0 & 15 & & \\
\cline { 1 - 3 } Sum & 75 & 75 & & \\
\hline
\end{tabular}


For auditors, weakness of academic education, with an average of 2.74 prevents the evaluation of internal control in independent auditing. Since the response mode is low option, and according to KHIDO amount (44.72) and its significant level (0.000) which is less than (0.01), about 99 percent we can say, lack of academic training prevents the evaluation of internal control in independent auditing.

Third Hypothesis: To determine whether the lack of professional training, precluding the evaluation of the internal control in independent auditing or not? The KHIDO test was carried out on the basis of responses received from the directors and partners of the audit firms.

Table 10: Descriptive Information about The Third Hypothesis By administers

\begin{tabular}{|l|c|c|c|c|}
\hline & Observed amount & Expected amount & KHIDO value & Significant- level \\
\hline Very low & 7 & 15 & & \\
\cline { 1 - 3 } Low & 51 & 15 & \multirow{3}{*}{42.56} & \multirow{2}{*}{0.000} \\
\cline { 1 - 3 } Average & 17 & 15 & \\
\cline { 1 - 3 } High & 0 & 15 & & \\
\cline { 1 - 3 } Very high & 0 & 15 & 75 & \\
\cline { 1 - 3 } Sum & 75 & & & \\
\hline
\end{tabular}

For managers, not affordable cost, with an average score of 2.13, prevents the evaluation of internal control in independent system. Since the response mode is average option, and according to KHIDO amount (42.56) and its significant level (0.000) which is less than (0.01), about 99 percent we can say, not affordable cost prevents the evaluation of internal control in independent auditing.

Table 11: Descriptive Information about the Third Hypothesis From auditor's Perspective

\begin{tabular}{|l|c|c|c|c|}
\hline & The observed value & The expected value & KHIDI VALUE & Significant level \\
\hline Very low & 0 & 15 & & \\
\cline { 1 - 3 } Low & 0 & 15 & \multirow{3}{*}{32.96} & \multirow{2}{*}{0.000} \\
\cline { 1 - 3 } Average & 7 & 15 & & \\
\cline { 1 - 3 } High & 47 & 15 & & \\
\cline { 1 - 3 } Very high & 21 & 15 & 75 & \\
\cline { 1 - 3 } Sum & 75 & & & \\
\hline
\end{tabular}

For auditors, not affordable cost, with an average of 4.18 prevents the evaluation of internal control in independent auditing. Since the response mode is high option, and according to KHIDO amount (32.96) and its significant level (0.000) which is less than (0.01), about 99 percent we can say, not affordable cost prevents the evaluation of internal control in independent auditing.

Fourth Hypothesis: To determine whether the lack of lack of suitable auditing procedures, precluding the evaluation of the internal control in independent auditing or not? The KHIDO test was carried out on the basis of responses received from the directors and partners of the audit firms

Table 12: Descriptive Information about the Fourth Hypothesis by Administers

\begin{tabular}{|l|c|c|c|c|}
\hline & Observed amount & Expected amount & KHIDO value & Significant- level \\
\hline Very low & 0 & 15 & & \\
\cline { 1 - 3 } Low & 0 & 15 & \multirow{3}{*}{14.52} & \multirow{2}{*}{0.000} \\
\cline { 1 - 3 } Average & 54 & 15 & & \\
\cline { 1 - 3 } High & 21 & 15 & 15 & \\
\hline Very high & 0 & 75 & & \\
\cline { 1 - 3 } Sum & 75 & & & \\
\hline
\end{tabular}

For managers, lack of suitable auditing procedures, with an average score of 3.28, prevents the evaluation of internal control in independent system. Since the response mode is average option, and according to KHIDO amount (14.52) and its significant level (0.000) which is less than (0.01), about 99 percent we can say, lack of suitable auditing procedures, prevents the evaluation of internal control in independent auditing. 
Table 13: Descriptive Information About The 4th Hypothesis From Auditors`S Perspective

\begin{tabular}{|l|c|c|c|c|}
\hline & The observed value & The expected value & KHIDI VALUE & Significant level \\
\hline Very low & 0 & 15 & \multirow{3}{*}{$*$} & \\
\cline { 1 - 3 } Low & 6 & 15 & \multirow{2}{*}{60.06} & \\
\cline { 1 - 3 } Average & 48 & 15 & & \\
\cline { 1 - 3 } High & 17 & 15 & & \\
\hline Very high & 4 & 15 & & \\
\cline { 1 - 3 } Sum & 75 & 75 & & \\
\hline
\end{tabular}

For auditors, lack of suitable auditing procedures, with an average of 3.25prevents the evaluation of internal control in independent auditing. Since the response mode is average option, and according to KHIDO amount (66.06) and its significant level $(0.000)$ which is less than (0.01), about 99 percent we can say, lack of suitable auditing procedures prevents the evaluation of internal control in independent auditing.

Fifth Hypothesis: To determine whether the low fee of auditing agreements, precluding the evaluation of the internal control in independent auditing or not? The KHIDO test was carried out on the basis of responses received from the directors and partners of the audit firms.

Table 14: Descriptive Information about the Fifth Hypothesis By administers

\begin{tabular}{|l|c|c|c|c|}
\hline & Observed amount & Expected amount & KHIDO value & Significant- level \\
\hline Very low & 1 & 15 & & \\
\cline { 1 - 3 } Low & 35 & 15 & \multirow{3}{*}{98.31} & \multirow{2}{*}{0.000} \\
\hline Average & 37 & 15 & & \\
\cline { 1 - 3 } High & 1 & 15 & & \\
\cline { 1 - 3 } Very high & 1 & 15 & & \\
\cline { 1 - 3 } Sum & 75 & 75 & & \\
\hline
\end{tabular}

For managers, low fee in auditing agreements, with an average score of 2.45 , prevents the evaluation of internal control in independent system. Since the response mode is low option, and according to KHIDO amount (98.31) and its significant level $(0.000)$ which is less than (0.01), about 99 percent we can say, low fee of auditing agreements, prevents the evaluation of internal control in independent auditing.

Table 15: Descriptive Information About The Fifth Hypothesis From Auditors' Perspective

\begin{tabular}{|l|c|c|c|c|}
\hline & The observed value & The expected value & KHIDI VALUE & Significant level \\
\hline Very low & 0 & 15 & \multirow{3}{*}{$*$} & \\
\cline { 1 - 3 } Low & 2 & 15 & \multirow{2}{*}{0.000} \\
\cline { 1 - 3 } Average & 34 & 15 & \\
High & 34 & 15 & \\
\cline { 1 - 3 } Very high & 5 & 15 & & \\
\cline { 1 - 3 } Sum & 75 & 75 & \\
\hline
\end{tabular}

For auditors, low fee auditing agreements, with an average of 3.76 prevents the evaluation of internal control in independent auditing. Since the response mode is average option, and according to KHIDO amount (41.04) and its significant level $(0.000)$ which is less than (0.01), about 99 percent we can say, low fee auditing agreements prevents the evaluation of internal control in independent auditing.

Sixth Hypothesis: To determine whether the traditional system of business units, precluding the evaluation of the internal control in independent auditing or not? The KHIDO test was carried out on the basis of responses received from the directors and partners of the audit firms. 
Table 16: Descriptive Information About The Fifth Hypothesis By administers

\begin{tabular}{|l|c|c|c|c|}
\hline & Observed amount & Expected amount & KHIDO value & Significant- level \\
\hline Very low & 0 & 15 & & \\
\cline { 1 - 3 } Low & 2 & 15 & \multirow{3}{*}{40.85} & \multirow{2}{*}{0.000} \\
\cline { 1 - 3 } Average & 34 & 15 & & \\
\cline { 1 - 3 } High & 34 & 15 & & \\
\cline { 1 - 3 } Very high & 5 & 15 & & \\
\cline { 1 - 3 } Sum & 75 & 75 & & \\
\hline
\end{tabular}

For managers, traditional system of business units, with an average score of 3.55, prevents the evaluation of internal control in independent system. Since the response mode is average option, and according to KHIDO amount (49.85) and its significant level (0.000) which is less than (0.01), about 99 percent we can say, traditional system of business units, prevents the evaluation of internal control in independent auditing.

Table 17: Descriptive Information about The Sixth Hypothesis From auditor's Perspective

\begin{tabular}{|l|c|c|c|c|}
\hline & The observed value & The expected value & KHIDI VALUE & Significant level \\
\hline Very low & 0 & 15 & \multirow{3}{*}{105.74} & \multirow{2}{*}{0.000} \\
\cline { 1 - 3 } Low & 6 & 15 & & \\
\cline { 1 - 3 } Average & 57 & 15 & & \\
\hline High & 10 & 15 & & \\
\cline { 1 - 3 } Very high & 2 & 75 & & \\
\cline { 1 - 3 } Sum & 75 & 15 & & \\
\hline
\end{tabular}

For auditors, traditional system of business units, with an average of 3.10 prevents the evaluation of internal control in independent auditing. Since the response mode is average option, and according to KHIDO amount (105.74) and its significant level (0.000) which is less than (0.01), about 99 percent we can say, traditional system of business units prevents the evaluation of internal control in independent auditing.

\subsubsection{Freedman Test For Ranking Barriers To Evaluate Internal Controls In The Independent Auditing:}

In order to rank the barriers to internal control evaluation in an independent auditing from the view of administrators and auditors, the freedman test was used.

Table 18: Ranking The Barriers To Internal Control Evaluation In An Independent Auditing From The View Of Administrators And Auditors

\begin{tabular}{|l|l|c|c|}
\hline Organizational post & component & Mean score & Rank \\
\hline \multirow{5}{*}{ Managers } & Lack of professional trainings & 3.56 & 4 \\
\cline { 2 - 4 } & Lack of academic trainings & 5.34 & 1 \\
\cline { 2 - 4 } & Not affordable cost of assessment of internal controls & 1.63 & 6 \\
\cline { 2 - 4 } & Lack of appropriate auditing procedures & 3.79 & 3 \\
\cline { 2 - 4 } & Low fee of audit contracts & 2.29 & 5 \\
\cline { 2 - 4 } & Traditional systems of business units & 4.39 & 2 \\
\hline \multirow{5}{*}{ Auditors } & Lack of professional trainings & 3.86 & 3 \\
\cline { 2 - 4 } & Lack of academic trainings & 2.03 & 6 \\
\cline { 2 - 4 } & Not affordable cost of assessment of internal controls & 5.06 & 1 \\
\cline { 2 - 4 } & Lack of appropriate auditing procedures & 3.09 & 4 \\
\cline { 2 - 4 } & Low fee of audit contracts & 4.25 & 2 \\
\cline { 2 - 4 } & Traditional systems of business units & 2.71 & 5 \\
\hline
\end{tabular}

As shown in Table 18, in the view of directors, lack of academic education, traditional system of business units and low fee of auditing contracts, are three important factors in assessing barriers of internal controls in independent auditing. But from the perspective of accountants, not affordable cost in evaluating the internal controls, low fee of auditing agreements 
and lack of professional trainings are the three main factors in barriers assessment of internal control in independent auditing.

\subsubsection{The T-Test To Evaluate The Opinion Of The Auditors And Managers In Barriers Assessment Of Internal Control In Independent Auditing.}

To determine the views of auditors and directors in barriers assessment of internal control in independent auditing, we used the t-test.

Table 19: Results Of The T-Test To Evaluate The Differences Between Views Of Managers And Auditors In Barriers Assessment Of Internal Control In Independent Auditing

\begin{tabular}{|c|c|c|c|c|c|c|}
\hline Component of questionnaire & Position & Mean score & Standard deviation & Degree of freedom & $\mathrm{F}$ & Sig. \\
\hline \multirow{2}{*}{ Lack of professional trainings } & Managers & 3.14 & \begin{tabular}{|c|}
0.48 \\
\end{tabular} & \multirow{2}{*}{148} & \multirow{2}{*}{26.31} & \multirow{2}{*}{0.000} \\
\hline & Auditors & 3.61 & 0.71 & & & \\
\hline \multirow{2}{*}{ Lack of academic education } & Managers & 4.10 & 0.58 & \multirow{2}{*}{148} & \multirow{2}{*}{0.32} & \multirow{2}{*}{0.000} \\
\hline & Auditors & 2.74 & 0.52 & & & \\
\hline \multirow{2}{*}{ Not affordable cost in eval. of internal controls } & Managers & 2.13 & 0.55 & \multirow{2}{*}{148} & \multirow{2}{*}{1.03} & \multirow{2}{*}{0.000} \\
\hline & Auditors & 4.18 & 0.58 & & & \\
\hline \multirow{2}{*}{ Lack of suitable accountancy procedures } & Managers & 3.28 & 0.45 & \multirow{2}{*}{148} & \multirow{2}{*}{4.98} & \multirow{2}{*}{0.77} \\
\hline & Auditors & 3.25 & 0.67 & & & \\
\hline \multirow{2}{*}{ Low fee of auditing agreements } & Managers & 2.54 & 0.62 & \multirow{2}{*}{148} & \multirow{2}{*}{4.93} & \multirow{2}{*}{0.000} \\
\hline & Auditors & 3.76 & 0.54 & & & \\
\hline \multirow{2}{*}{ Traditional systems of commercial units } & Managers & 3.56 & 0.66 & \multirow{2}{*}{148} & \multirow{2}{*}{16.90} & \multirow{2}{*}{0.000} \\
\hline & Auditors & 3.10 & 0.55 & & & \\
\hline
\end{tabular}

Significant lower level of 0.05 indicates the meaningful difference between auditors and managers in researched component. As you can see, all the mentioned components, except the lack of appropriate auditing procedures, have meaningful difference. This means, auditors and managers except the component of lack of appropriate auditing procedures, have quite different views about evaluation barriers of internal controls in internal auditing and its value.

\section{Discussion and Conclusion}

In view of administrators, evaluation barriers in internal control in order of priority are:

IN VIEW OF MANAGERS:

1) Lack of academic training

2) Traditional system of business units

3) Lack of business units systems

4) Weakness of professional trainings

5) Low fee of auditing agreements

6) Not affordable cost of evaluation in internal controls

IN VIEW OF ACCOUNTANTS:

1) Not affordable cost of evaluation in internal controls

2) Low fee of auditing agreements

3) Weakness of professional trainings

4) Lack of suitable auditing procedures

5) Traditional systems of business units

6) Weakness of academic trainings

As you can see, from the view of administrators, poor academic training with an average rating of $5 / 34$, is the main evaluation barrier of internal control in independent auditing, which shows in adequate educational resources for evaluation of internal controls in independent auditing, university professors are not dominant in performance issues of evaluation in internal controls in independent auditing and undeveloped process of academic education in auditing issues, particularly evaluation of internal controls. This result, was accepted in previous researches and the plan is open in relation to the auditing training in universities. 
Second priority by administrators is related to traditional system of business units with an average rating of 4.39 , precludes the evaluation in independent auditing, which indicates there is no effective internal auditing in big companies or there is no effective use of them, there is no competitive atmosphere, managers of business units try to use uneconomical relations, majority of directors of business units have no believe to establish a perfect system for internal control and continuous changes in managers of business units (No permanent management).

Basically, internal controls of Iranian business units were not taken seriously, because the economical atmosphere of our country is not competitive. And in this situation, managers have more attention in using the uneconomical relations. So, they will be having good attention to internal controls.

From the view of administrators, third priority is related to lack of suitable auditing procedures with average ranking of 3.79 is an obstacle for evaluation of internal auditing in independent auditing. This shows the managers have knowledge about lack of proper and efficient guidelines for suitable auditing for internal control evaluation in economical units. From the audit perspectives, not affordable cost of internal control evaluation and low fee of auditing agreements are the main obstacles for internal control evaluation in independent auditing which got the mean ratings of 5.06 and 4.25. For auditors, using students and unskilled clerks in auditing firms and in the result, they have no ability to do the internal control evaluation, seasonable auditing, time pressure to finish auditing process in fixed period of time, small size of business units who are under study are the reasons to be called not affordable cost for internal control evaluation. This issue will attract students who are relatively cheaper forces which naturally affects the quality of audit work.

In conclusion, we can say, directors and auditors have different views on internal control evaluation in independent auditing. As managers say, weakness in auditing training is the main reason, while the auditors, recognize the low fee and not affordable cost of internal control evaluation are the actual reasons in internal control evaluation of independent auditing.

\subsection{Limitation of Research}

1) Due to geographical spreading of auditors throughout the country, and existence of many problems for reaching to them for the sake of questionnaire distribution, statistical society is limited to auditing firm partners who are members in official auditing society of Iran, situated in Tehran city and managers and managing committee of some of the manufacturing factories in Tehran.

2) Lack of confidence in some staff to researcher to complete the questionnaire.

3) The long duration in answering the questions was another problem in this research.

4) Lack of research vision among some employees, was the cause for incomplete questionnaire.

\subsection{Suggestions}

We should consider the weakness in academic training is because, there is no relation between industry and university. Some people think, relation between university and industry should be on the field of engineering and do not care about natural science courses, especially auditing. But forming and continuation of business units activity is related to such science. Every business unit needs professional force for management, and using these forces in auditing and financial matters are essential. And training of these fellows are duties of th universities.

Unfortunately, some students after graduation and joining the profession in the field of auditing are suffering, because their information from the university is not related to industry needs. There is no relation between industry and university, commercial unit needs are not recognized, accurately. And university subjects are far from real needs.

Weakness in professional and academic trainings from both the group of managers and auditors are the main cause in evaluation obstacles of internal controls in independent auditing. Therefore education in auditing profession should be verified. Auditing fee is one the main issues in the struggle of auditors in recent years. Auditors feel the fee is low but in practice, managers hesitate to increase the fee, and this action will affect the work of auditors in evaluation of internal controls, there should be change in rules. So fee of accountants must be paid according to their effort.

\section{References}

Abu Thahir, A., Abdul Wahid, E., \& Syed Mustapha Nazri, S. (2006). Auditor-client relationship: the case of audit tenure and auditor switching in Malaysia. Managerial Auditing Journal, 21(7), 724-737. doi:http://dx.doi.org/10.1108/02686900610680512

Agaser, G. M., \& Doupnik, T. (1991). Perceptions Of Auditor Independence: A Cross - cultural Study. International Journal Of Accounting, 6, 220-237. 
Banimahd, B. (2012). Investigation of Some Determinants on Unqualified Audit Opinion. Quarterly Journal of Securities Exchange, 4(13), 59-83. Retrieved from http://www.magiran.com/view.asp?Type=pdf\&ID=946392\&l=en

Bartlett, R. W. (1993). A Scale of Perceived Independence : New Evidence on an Old Concept. Accounting, Auditing and Accountability Journal, 6('2), 52-67.

Beattie, V., Brandt, R., \& Fernley, S. (1999). Perceptions of Auditor Independence: UK Evidence. Journal of International Accounting Auditing \& Taxation, 8(1), 67-107.

Bell, T., \& Tabor, R. (1991). Empiricalanalysis of audit uncertainty qualifications. Journal of Accounting Research, 29, 350-370.

CICA. (2000). Independence Standards Exposure Draft. Canadian Institute of Chartered Accountants.

Crasewell, A., Francis, J., \& Taylor, A. (1995). Auditor Brand Name Reputations and Industry Specializations. Journal of Accounting and Economics, 20, 297-322.

Datar, S., Feltham, G., \& Hughes, J. (1991). The Role of Audits and Audit Quality in Valuing New ;ssues. Journal of Accounting and Economics, 14, 3-49.

Dopuch, N., \& Simunic, D. (1980). The Nature of Compettion in the Auditing Profession,Auditing Profession:Adescriptive and Nomative View. The Illinois Auditing Symposium.

Ebrahimi Kordlar, \& Seyyedi. (2008). Independent auditor's role in reducing discretionary accruals. Iranian Journal of Accounting and Auditing Review, 54, 3-16.

Geiger, M. A., K, R., \& Dasaratha, v. R. (2005). Recent Changes in the Association between Bankruptcies and Prior Audit Opinion "Auditing. A Journal of Practice \& Theory, 24(1), 21-35. Retrieved from http://journal.seo.ir/page/download-WTIWcoGKtFs.artdl

Ghadimi, M. (2004). Evaluation auditing standards developed by professional associations and publications, internal and external validity of the internal control (Thesis). Iran.

Gul, F. A. (1989). Bankers Perceptions of Factors Affectig Auditor Independence. Accounting , Auditing \& Accountability Gournal, 2(3), 40-51.

Hudaib, M., \& Cooke, T. E. (2005). The Impact of Managing DirectorChanges and Financial Distress on Audit Qualification and Auditor Switching. Journal of Business Finance \& Accounting, 32(9), 1703-1739.

Independence Standards Board (ISB). (1999). Independeence Discussions With Audit Committees. ISB Standard No 1. Retrieved from www.cpaindependence.org

International Federation of Accountants. (2001). Code of Ethics forProfessional Accountansts. IFAC.

Jameei, R., Hashemi, M., \& HajiAbdi, A. (2012). The effect of managers' performance on the independent auditor's opinion on the companies listed in Tehran Stock Exchange. Accounting and Auditing Review, 19(70). Retrieved from http://www.magiran. com/view.asp?Type=pdf\&ID=1144146\&l=fa

Lindsay, D. (1990). An Investigation of the Impact of Contextual Factorson Canadian Bankers,s perceptios of Auditor,s Ability to Resist Management Pressure. Advances in Internaional Accounting, 3, 71-85.

Maham, K. (2002). Identifying barriers to evaluate internal controls in the independent audit. Iranian Journal of knowledge of Auditing, $147,62-79$.

Maham, K., \& Pooryanasab, A. (2004). Internal Control - Integrated Framework: evaluation instruments. Tehran, Iran: Auditing Organization, Standards Management . Retrieved from http://www.ketab.ir/bookview.aspx?bookid=1496814

Mahan, K., \& Takroosta, M. (2012). Identifying barriers to evaluate internal controls in the independent audit. Iranian Journal knowledge of Auditing, 12(46), 62-79. Retrieved from http://www.ensani.ir/storage/Files/20121210083949-9414-74.pdf

Malekian, E., Tavakolnia, E., \& Pakdelan, S. (2014). Assessment of internal controls by management and independent auditors and disclosure of information. Second National Conference of accounting, financial management and investment. Gorgan: Association of Professional Managers and Accountants Golestan. Retrieved from http://www.civilica.com/Paper-CAFM02CAFM02_477.html

Park, S. H. (1990). CompetitionmIndependence and Audit Quality: the Korean Experience. The Inter national of Accounting, 25, 71-86.

Preparation committee for standard accounting. (2010). Auditing Standards. (10, Ed.) Tehran, Iran: Press Center Accounting and Auditing Auditing Organization. Retrieved from http://audit.org.ir/

Rajabi, R., \& MohammadiKhashoee, H. (2008). Independent auditing agency costs and pricing. Iranian Journal of Accounting And Auditing Review, 53, 35-52.

Rezaei, M. (1996). Analysis of the independent auditors' reliance on internal controls and auditing firms (MS Thesis).

Sajjadi, S., \& Ebrahimimand, M. (2005, Spring). The benefit of an independent auditing of financial statements. The Iranian Accounting and Auditing Review, 12(2), 61-81. Retrieved from https://acctgrev.ut.ac.ir/article_10480_1051.html

Sajjadi, S., \& Naseh, L. (2003). The benefit of an independent audit of financial statements. Iranian Journal of Accounting and Auditing Review(10), 65-91. Retrieved from https://acctgrev.ut.ac.ir/article 10444 1044.html

Shockley, R., \& Shceifler, S. (1984, October). Pereception of Auditors Independence:An Emprial Analysis. The Accounting Review, 785800.

Tehran Stock Exchange Organization. (2012). Guidelines internal controls. Securities and Exchange Organization. tehran: Tehran Stock Exchange. Retrieved from http://rdis.ir/Guidelines.asp

The Chartered Institute of Management Accountant. (2001). An independent view on theindependence of auditors: CIMA Review of Auditor Independence. CIMA. Retrieved from http://www.law.unimelb.edu.au/files/dmfile/cimaglobal1.pdf

Thoh, H. Y., \& Lim, C. (1994, April). Pereception of Auditors Independence:A Malaysian Study,Report Prepared for the Malaysian Institute of Accounts. Malaysian: Malaysian Institute of Accounts. 
Titman, S., \& Truemanm, B. (1986). Infoemation, Quality and the Valuation of New Issues. Journal of Accounting and Economics, 8, $159-172$.

Vadiee, M., \& Kouchaki, S. (2008). Evaluate the effectiveness of internal control system from the perspective of independent auditors and its impact on auditing process. Iranian Journal of Development and Investment, 1(2), 127-147. 